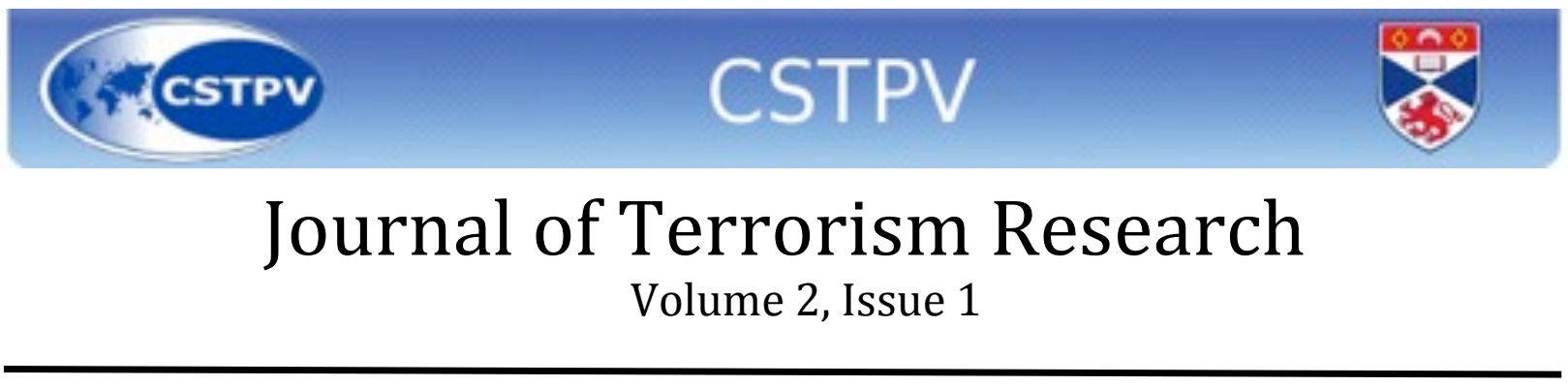

\title{
Decentralised Leadership in Contemporary Jihadism: Towards a Global Social Movement
}

\section{by Romain Bartolo}

On October 19 $19^{\text {th }} 2003$, nearly six months after the outset of the invasion of Iraq by US troops, a video was released by al-Qaeda media arm al-Sahab showing Osama bin Laden directly threatening Spain. In his words, Spain, then governed by Prime Minister José Maria Aznar from the Partido Popular (PP), may face a terrorist attack should Spanish military forces continue to be part of the coalition that invaded Iraq[1] and toppled the Saddam Hussein regime. Less than six months later, on March $11^{\text {th }}$ 2004, Madrid was shaken by coordinated bomb attacks in several commuter trains at peak hours, killing 191 people and wounding thousands. The "first wellknown al-Qaeda-inspired terrorist conspiracy in Europe"[2] had been in preparation for years thanks to the long-term presence of radical Islamists on Spanish soil. The first jihadist bombing on this continent since 9/11[3] seemed to have answered Osama bin Laden's warning call. Those who later claimed responsibility for these attacks pointed out Iraq as their main source of motivation. Symbolically the bombings were carried out a few days before the first anniversary of Iraq's invasion. On the national scene, because "terrorism is meant to terrify"[4] and affect an audience, terrorists clearly intended to affect the outcome of the national general elections scheduled three days later. The Madrid terrorists were not self-starters, nor were they members of al-Qaeda who had performed an oath of allegiance to bin Laden. Instead, they were mostly firstgeneration immigrants from Northern Africa or the Near East who had been settled in Spain for years, had decent jobs and for some of them wives and children[5]. The setting up of the Madrid bombings was an illustration of the rising context of the contemporary jihadist movement, targeting a country and blaming it for what was happening thousands of kilometres away. This example is highly valuable to describe the continuously evolving nature of the jihadist movement up to now.

\section{A splinter group within Islamism}

The contemporary jihadist movement, be it nicknamed "leaderless jihad"[6], "jihadi international"[7], "neojihadism"[8] or the "global social movement"[9], has progressively broken away from modern Islamism as embodied by Hasan al-Banna[10], Sayyid Qutb, Mawdudi or Ayatollah Khomeini. Islamism was conceptualised as a political ideology that aimed to Islamise society and state through the enforcement of sharia and to revive the value of Islam 


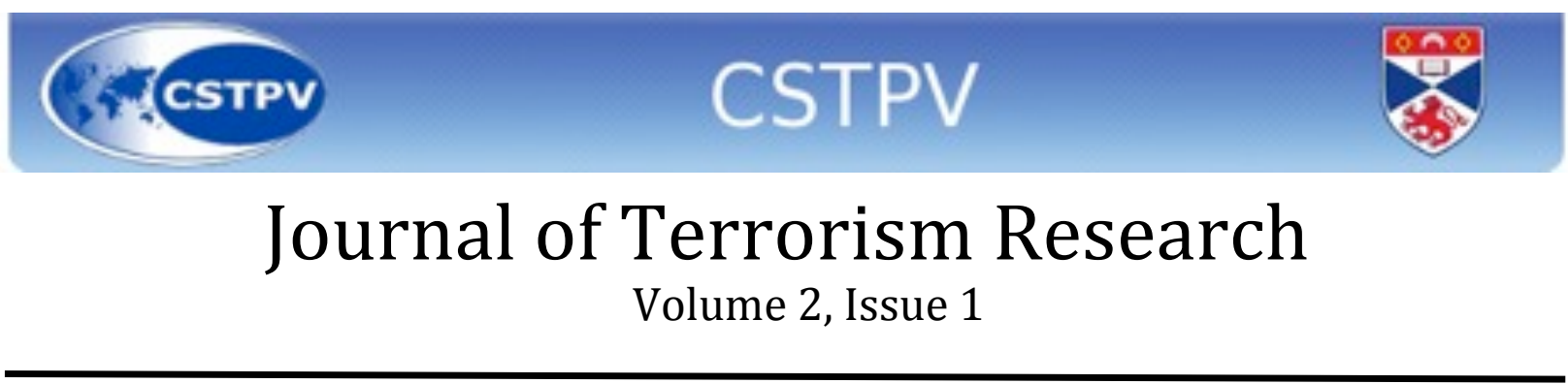

as a cornerstone of socio-political life[11]. By the time Islam had become a powerful rallying tool to oppose governments, most Muslim countries had secular and nationalist regimes such as Egypt, Iraq or even Indonesia[12]. In the wake of the successive waves of independence in the second half of the twentieth century, radical Islam progressively affected other Muslim countries. Over the last thirty years, radical Islamist groups have extensively referred to the concept of jihad. Jihad has increasingly been conceived by these groups as armed struggle wherever Muslims are oppressed. Islam is not a monolithic block[13], like Islamism and its various subcategories[14]. There has been growing disagreement and opposition between the Egyptian Muslim Brotherhood, a socio-political mass organisation that has engaged in politics when not banned by successive Egyptian regimes, and Salafi-jihadist groups such al-Qaeda or Algerian Islamic Armed Group (GIA)[15]. The opposition lies on various points that nurture heated debate within Islamist circles, and illustrates perfectly that a wide array of schools of thought exists in political Islam. Indeed, mainly symbolised by the showdown between the Muslim Brotherhood and al-Qaeda, disagreements lie in issues such as democracy, takfir (declaring Muslims to be apostates), or the carrying out of indiscriminate violence towards civilians on American and European soils[16]. The Muslim Brotherhood condemned the 9/11 attacks, Abu Musab alZarqawi's call to kill Shia in Iraq and more generally al-Qaeda terrorist agenda[17]. The fact that al-Qaeda deputy leader Ayman al-Zawahiri went online in April 2008 to answer questions and criticise the Muslim Brotherhood[18] strikingly shows that, within a broad Islamist movement united by the promotion of a pro-Islamist political agenda, tactics and strategies differ highly from one organisation to another.

Jihadism in its current form is not homogenous either. Most jihadist groups are of SalafiWahhabi tradition, an extremist branch of Sunni Islam that is known for its "selectively literal interpretation of [Islam's] sacred texts"[19]. It is essential to bear in mind that the Salafi movement is heterogeneous and made up of different factions and schools of thought. As illustrated by Quintan Wiktorowicz, "the Salafi movement [...] reflects a broad array of positions regarding issues related to politics and violence"[20]. Particularly, three different factions are to be distinguished within Salafism: "purists" who are nonviolent, do not engage in politics and who focus on $d a$ ' $w a$ and religious education; "politicos" who "emphasize the application of the Salafi creed to the political arena"[21]; and jihadis favouring violence to establish Islamic states [22]. Nevertheless, all factions share common beliefs such as the concept of tawhid, or the unity and uniqueness of God. They unanimously reject religious innovation and interpretation, and consider the Koran and Sunna to be the only legitimate sources of law. Referred to as aqida, this "common religious creed revolves around strict adherence to the concept of tawhid and ardent 


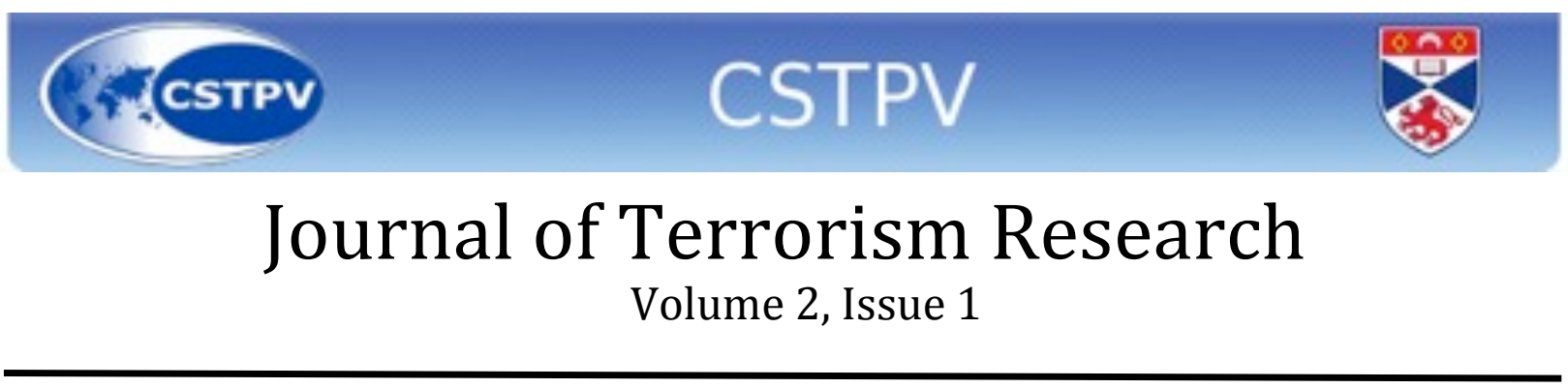

rejection of a role for human reason, logic, and desire"[23]. Besides this, there is a common rejection of Western culture, and a willingness to avoid interactions with non-believers[24]. Where factions disagree is on the context and the interpretation of contemporary affairs, also illustrated by the words of a Jordanian jihadi leader, "the split is not in thought; it is in strategy"[25].

The contemporary jihadist movement does not follow the legacy of modern Islamism and is in fact a violent and "extremist splinter group within Islamism"[26] that makes jihad a necessary and individual task. According to Petter Nesser, jihadist terrorists:

see terrorism as a legitimate and necessary means of struggle in a campaign aiming to: 1 . Re-Islamize the Muslim world by toppling local regimes they accuse of having become too secular and too dependent on the West, and, 2. Rid Muslim lands of Western influences[27].

Indeed, jihadists have been fighting two enemies at the same time, the "near enemy"[28] and the "far enemy". The near enemy was until recent times the most important target in the eyes of Islamists. However, the gradual failure to topple secular regimes has led them to embrace a more international type of struggle.

\section{The Afghan catalyst}

The Salafi-Wahhabi jihadist movement is particularly embodied by al-Qaeda[29], and a wide array of associated groups across the world. Members of these extremist groups were galvanised by the defensive jihad in Afghanistan when thousands of foreign fighters came to this mountainous country to fight the Soviet forces and defend what they perceived as a collective duty to protect their brothers of Islam. Despite a relatively poor role in defeating the Soviet military, the 'Afghan Arabs' boasted about having successfully brought to its knees one of the world's two superpowers. While it united mujahideen in the 1980s, its aftermath led to heated debates within jihadist circles regarding the tactics and the strategy to embrace for the future[30]. Some Afghan veterans brought the experience and taste of jihad home, to Indonesia, the Philippines, Algeria, Bosnia, the West and many more places throughout the Muslim world[31].

Firstly, in today's era, the jihadist movement would certainly be well described as a global social movement that has nurtured radicals around a common ideology. French sociologist Alain 


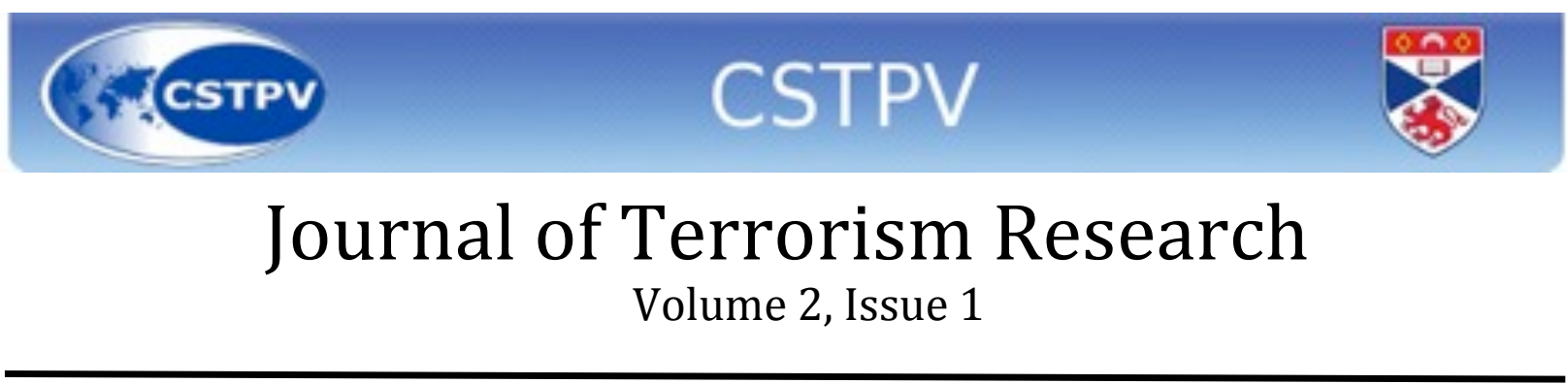

Touraine defines a social movement as "an answer either to a threat or a hope that is directly linked to the control that a social group has over its capacity to make decisions, to control changes and so on"[32]. Following 9/11, the threat of jihadism has spread out, gained a global audience, widened the theatre of actions[33] and threatened an increasing number of targets. Contemporary jihadism truly defines itself as a global social movement. As Michel Wieviorka pointed out in his study of global anti-movements in the globalised age, the preparation of the 9/11 attacks involved individuals located on four different continents. The 9/11 hijackers, except for one, were born in Egypt and Saudi Arabia. Four hijackers had socialised in Germany during their university education and had formed the Hamburg cell, later moving to the United States in order to learn how to fly planes. Meanwhile, al-Qaeda Central had settled in Sudan in the 1990s before moving to Afghanistan and setting up training camps for jihadi candidates[34]. The major change suffered by the jihadist movement deals with the huge structural shift undergone by alQaeda, the main spokesperson of global jihadism, into a rallying cry for radical Islamists and angered Muslims. Secondly, due to the decentralised nature of jihadism, leadership has been affected. It has become less centralised[35] and relied on Osama bin Laden, at least until his death was announced on May $2^{\text {nd }}, 2011$, as a strategic leader and a uniting spiritual figurehead rather than a military commander that sends direct orders to jihadists on the field. Nonetheless, less centralised leadership does not imply 'leaderless jihad'. Instead, accounts of the most recent terrorist attacks carried out in the name of al-Qaeda in its loosest sense since 9/11 suggest they were the result of radical local groups and networks linked through friendship, kinship and word of mouth contacts rather than the outcomes of individual self-radicalisations.

\section{The appeal of al-Qaeda ideology: a driver of franchised jihadism}

Following increasing contacts and collaborations between al-Qaeda and like-minded groups in the 1990s, the contemporary jihadist movement evolved into a more decentralised and fluid network. Jihadist groups have undergone a severe crackdown on their operational base since 9/11 but have managed to cope with it well. As Jason Burke asserts, "al-Qaeda has become more lethal as an ideology than as an organisation"[36]. As a "vanguard"[37] of Islamist international terrorism, al-Qaeda symbolises the evolution of the jihadist threat in the post-9/11 environment. In this new era, there is no central hub that serves as the main operational link between cells. Instead, cells do not cooperate with each other and do not generally know about the existence of other cells so as to reduce the likelihood of getting the whole picture if one cell is broken down. Consequently, "having no 'hub' to answer" contributes to minimise the impact of the destruction of individual cells on the organization as a whole"[38]. 


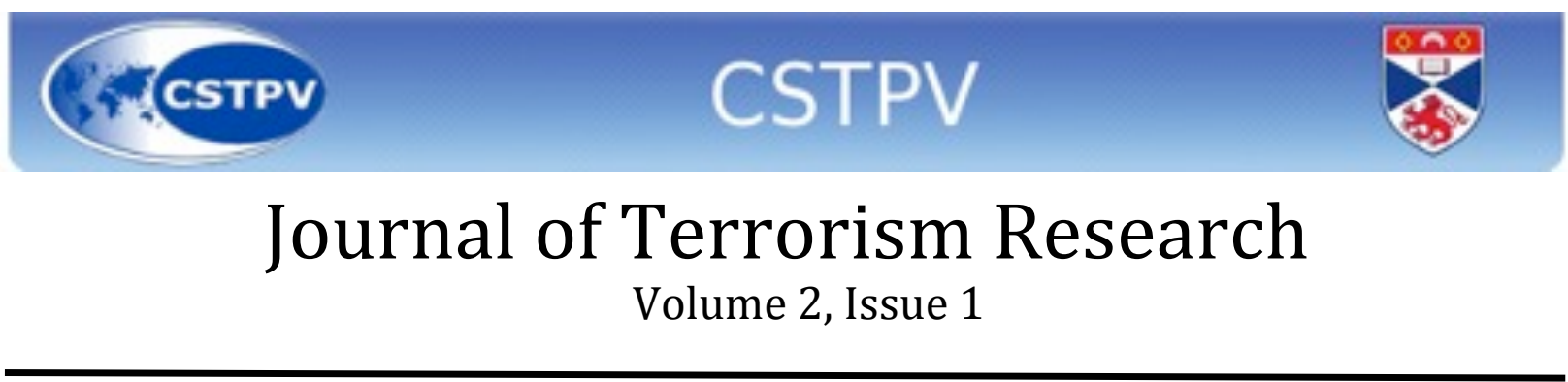

\section{Al-Qaeda, from a hierarchical organisation to the vanguard of jihadist terrorism}

First of all, as a major player within the jihadist movement, al-Qaeda has transformed itself from a hierarchical terrorist organisation into something that has more to do with an appealing ideology than a structured paramilitary organisation. Before $9 / 11$, jihadist attacks such as the 1998 East Africa embassy bombings and the 2000 USS Cole in Aden were directly linked to the core al-Qaeda spiritual and military leadership based in Afghanistan. Those who had set up the operations were al-Qaeda operatives who followed orders of the al-Qaeda shura, the organisation's decision-making body. At that time, jihadism had a clear command-and-control apparatus emanating from the top leadership. Besides, between 1996 and 2001, the Taliban regime in Afghanistan provided al-Qaeda with a safe haven for jihadist leadership. Meanwhile, about an estimated 20,000 estimated jihadists trained in al-Qaeda camps[39]. The loss of the Afghan safe haven following the wave of US bombings from October 2001[40] put al-Qaeda as an organisation under great pressure. Financial assets were frozen, training camps were destroyed, and militants as well as senior al-Qaeda members were tracked down, captured or killed. Al-Qaeda has survived the capture or death of " $80 \%$ of its global leadership structure"[41], such as military chief Mohammed Atef[42], Khalid Sheikh Mohammed[43], and al-Qaeda-Jemaah Islamiyah operative Hambali[44]. The organisation has proved to be highly resilient[45] and has successfully turned into a mass social movement attracting thousands of radicalised Muslims across the world. Indeed, the persistence of al-Qaeda as a terrorist threat does not lie in its military capabilities, which have been greatly hampered since 2001 . Rather, it goes well beyond these and deals with the attractiveness of jihadism to extremists, making alQaeda just part of a broader extremist Salafi-Wahhabi movement[46].

\section{The globalisation of jihadist militancy}

Owing to this new hostile international security context where most Western and non-Western states adopt a tough stance against terrorism, the form of jihadist terrorism has become more complex to deal with. While jihadist militancy remained mainly local and confined to national boundaries in the 1990s, jihadism over the last ten years seems to have moved beyond borders thanks to increasing cooperation between associated groups. Global jihadism advocates were able to accomplish what had failed in the 1990s in local jihads such as in Algeria and Bosnia[47], that is to say, the submission of local conflicts in which Islam plays a part to a global narrative that puts Islam at the core. Back in the 1990s, local jihadist groups had waged war on their 


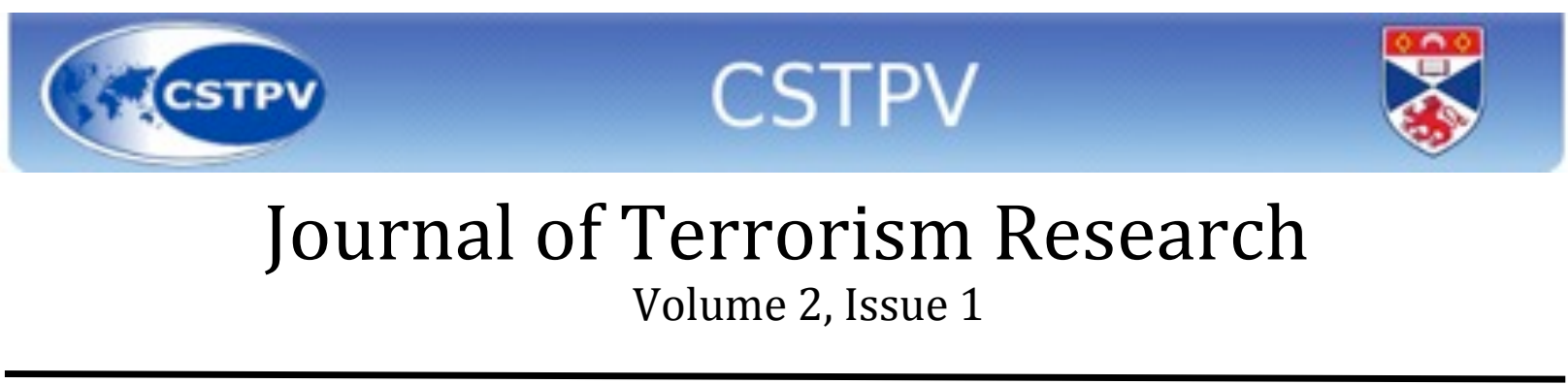

national governments but had been reluctant to join al-Qaeda's global struggle. These unsuccessful local jihads and "the subsequent failure to establish an Islamic state in a given country"[48] may have "pushed the Islamists to go "global""[49]. What can be said is that Osama bin Laden became a uniting point in jihadist militancy by gathering a large number of terrorist groups into his sphere of influence. Jihadist groups have adopted brand-new names that symbolically refer to the allegiance they pledged to the al-Qaeda agenda[50], such as al-Qaeda in the Arabian Peninsula (AQAP), al-Qaeda in the Land of Two Rivers and even al-Qaeda in the Islamic Maghreb (AQIM), an Algerian-based terrorist group formerly called Salafi Group for Call and Combat (GSPC)[51]. Leaders of these organisations swore their allegiance to Osama bin Laden, al-Qaeda and their strategic objectives. In his analysis of the GSPC as a "glocal terrorist organisation"'52], Jean-Luc Marret shows how internal debate within this group sparked tensions between on the one hand, those who wanted to keep the struggle local and, on the other hand, those who advocated going global. The contemporary jihadist movement has evolved thanks to the growing appeal of al-Qaeda ideology and personal links between high-profile terrorists. This naming illustrates the franchising of jihadism in the "age of networked terrorism"[53]. This mix of ideology and individuals has made the jihadist threat successful in its attempt to go global. Indeed, al-Qaeda and other extremist terrorist groups have all found common grounds to subscribe to this mutually beneficial relationship. By doing so, al-Qaeda offsets its operational disability to carry out another large-scale attack [54] and has increasingly relied on various affiliated terrorist groups, such as Jemaah Islamiyah, Pakistani Lashkar-e-Toiba or other European terrorist networks. Al-Qaeda, as a label, provided all these movements with the global audience they were looking for. It increases "public awareness" [55] of groups who are willing to publicise their cause. It is particularly relevant regarding the complicated relationship between terrorism and the media sphere. Because al-Qaeda-related terrorism has been, in general, defined as the most serious non-state threat to governments[56] lately, subscribing to alQaeda's worldwide agenda has given jihadists the opportunity to hit the headlines because of the media's attraction towards a "dramatizing effect"[57]. By the same token, the vanguard of jihadism benefited from this cooperation by claiming responsibility for the attack once it had already happened. Al-Qaeda strives to retrieve the political message sent by the terrorist attack and confer retrospectively its approval or refusal. The case of Nigerian 'underpants bomber' Omar Farouk Abdulmutallab may well fit the description of al-Qaeda's willingness to bless the failed plot. Marc Sageman's following words illustrate this trend: 


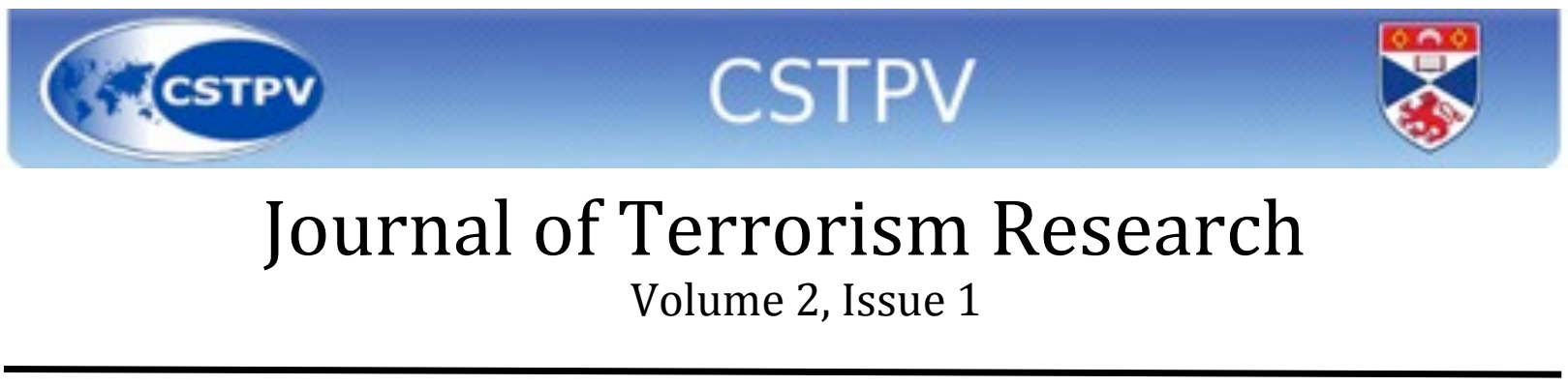

Their [adherents'] official acceptance into al-Qaeda comes after the fact, [...] al-Qaeda Central does not know who its followers are, and is reduced to accepting them after the adherents declare themselves in an act of terrorism[58].

This structural shift in the jihadist movement was made possible because al-Qaeda and Osama bin Laden had managed to create "a narrative"[59]. According to French scholar Olivier Roy:

The success of Osama bin Laden is not to have established a modern and efficient Islamist political organisation, but to have invented a narrative that could allow rebels without a cause to connect with a cause[60].

The "glocal" organisational structure of contemporary jihadism

The jihadist movement has been torn between globalism and localism. Nowadays, it seems that the tendency is leaning towards globalism but it is not an entirely pure global trend. Rather, we should adopt what Zygmunt Bauman conceptualises as "glocalisation". The contemporary jihadist movement fits the definition of a social movement given by Brian Jackson, who asserts that a social movement is "a group of people with a common ideology who try together to achieve certain general goals"[61], well. Despite being broad, this definition illustrates how today's jihadism has evolved - the original al-Qaeda network, by uniting around an openly violent ideology, into "ad-hoc terrorist networks, imitators, emulators and a strategic union of like-minded companies"[62]. Assuming that the globalisation of jihadism has reduced the importance of leadership may be misleading. The new face of contemporary jihadism still depends on leadership at some point and "it would be wrong to conclude that the central alQaeda organization is no longer a threat"[63].

From the end of a clear command-and-control leadership to a divided and decentralised leadership

Although Osama bin Laden gave the 9/11 hijackers his approval to go ahead with their plans, one cannot but notice that nowadays the jihadist movement goes well beyond him and al-Qaeda in terms of operational leadership and spiritual guidance. What Western and Muslim countries have dealt with for the last ten years differs from an organisation with a genuine command-andcontrol apparatus assessing targets, providing funds and carrying out the attack. Contemporary jihadism has shaken a large number of countries. The choice of targets has diversified, ranging 


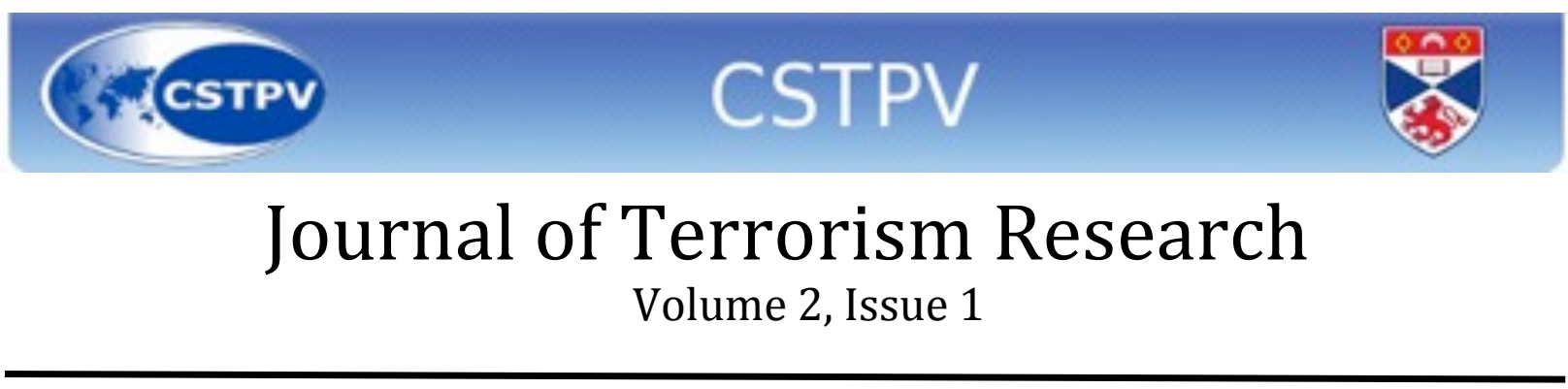

from police stations and embassies in Pakistan, religious buildings in Djerba to hotels in Jakarta, oil pipelines in Iraq and Saudi Arabia, or public transport in Madrid and London. In the same period of time, terrorist plots were foiled in Singapore, Scotland and Canada, and thousands of jihadist sympathisers were arrested in a dozen countries[64]. Clearly, post-9/11 jihadism does not rely on a small number of leaders, so "the death or incarceration of [its] leadership and severe losses to [its] membership [...] is not terminal to [its] struggle"[65]. The persistence of al-Qaeda as a common narrative has succeeded because leadership does not solely lie on the shoulders of high-profile international terrorists. Rather than a global one, leadership has become more local and fragmented at the operational level.

However, strategic leadership rested upon the shoulders and aura of Osama bin Laden, who, despite having been described as a modest and soft-spoken man by Western journalists[66], was an essential figurehead. Leadership within contemporary jihadism still matters, hence the limited ability of Internet self-radicalised individuals to go ahead with their self-organised plans. Leadership has expanded thanks to the use of the Internet[67], which has proven to be an efficient recruiting tool for de-territorialised jihadists - individuals that will cross the violence threshold based on an array of overseas events. Abu Musab al-Suri's plan is to urge would-be jihadists to train autonomously wherever they can in order to create "a system, not an organisation"[68]. Examples of "autonomous jihad"[69] are to be found in the cases of selfproclaimed cell leaders Abdul Nacer Benbrika in Australia and Mohammed Siddique Khan. Local imam in a Melbourne suburb, Benbrika was a "spiritual sanctioner"[70] of both Melbourne and Sydney cells, whose targets were official government buildings and a nuclear plant[71]. Trends in autonomous jihad are symbolised by Benbrika's own sanction of a suicide attack after the question was asked by a cell member[72]. In Khan's case, his decision to visit Pakistan[73] and engage in training with extremist groups in 2004 and 2005 illustrates his commitment to jihad and consequently his leadership within the four-man commando. These individuals "are not 'name-brand' terrorists or part of any known terrorist group" but rather "are like-minded individuals"[74] who were inspired by al-Qaeda, radicalised, indoctrinated and who progressively embraced jihad.

\section{The influence of jihadist leadership on European soil}

Many terrorist attacks were claimed to be carried out by self-starters, such as the London bombers or the murderer of controversial Dutch filmmaker Theo van Gogh. Further evidence showed a much deeper commitment to the global jihadist cause and decentralised leadership. 


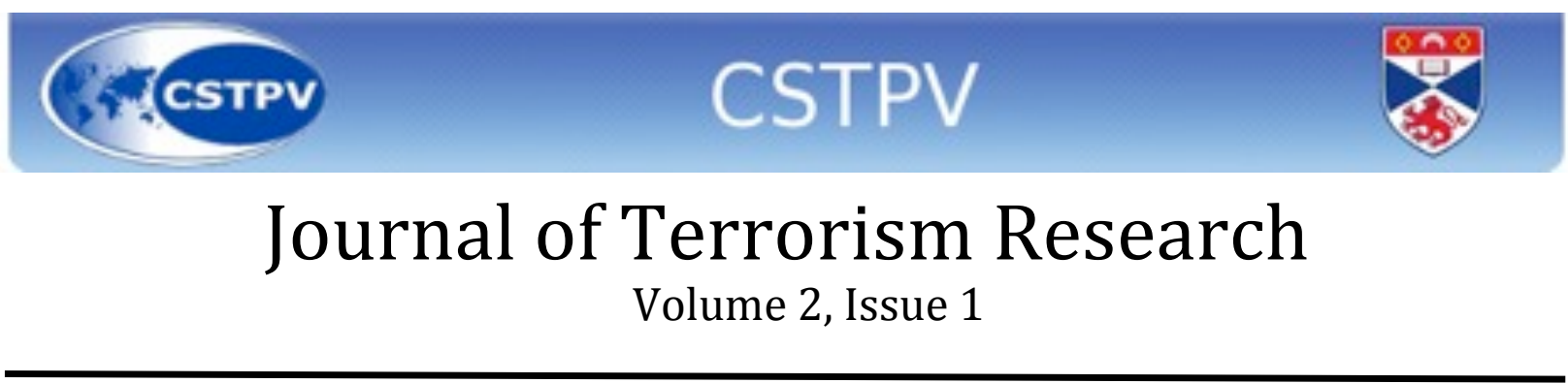

Mohammed Bouyeri, van Gogh's murderer, belong to the Hofstad Group, a Dutch jihadist group led by Syrian radical preacher Abu Khatib[75]. The very same group had plans to bomb Amsterdam international airport and government buildings[76]. The London bombers were all British citizens educated within the framework of the British system. Contacts with Pakistani groups were easily made through family acquaintances, given that cell leader Mohammed Siddique Khan and Shehzad Tanweer were of Pakistani descent and still maintained close links with their relatives in Pakistan. These two individuals kept contact with extremists in Pakistan and the UK “up until the attack itself'[77]. Therefore, it cannot be claimed that these attacks were solely grounded in a European context. To a certain extent, it shows how global the jihadist movement has become. British-born citizens[78] bombed their own country and killed their fellow citizens, blaming them for their indirect involvement in the killing of thousands of innocent Iraqis. The issue of leadership in this case clearly shows a cell leader, Mohammed Siddique Khan, an influential person, leading young radicals in their early twenties. More generally, dealing with the leadership of the contemporary jihadist movement has become as complex as dealing with the global jihadist ideology. Leadership has become more diffuse, whether it is operational, ideological, or due to the charisma of an individual. Osama bin Laden's success was grounded on his ability to co-opt like-minded terrorist groups and also to inspire a certain number of radical individuals or religious authorities to embrace his violent agenda and ideology. Since 9/11 and the structural change undergone by al-Qaeda into the franchising of Islamist terrorism, authority in the jihadist movement has been divided. Leadership and authority do not solely emanate from high-profile terrorists but also from radical imams who have extensive links with extremist groups overseas in Pakistan, Iraq or the Maghreb. In all instances of jihadism in post-9/11 Europe, "the Iraq war was a significant motivational factor for the Islamist terrorists"[79].

\section{Osama bin Laden, a uniting guide rather than a military leader}

Until early May 2011, Osama bin Laden remained a figurehead of the jihadist movement, even though authority and leadership have become less personalised. In a certain way, and despite the fact that contemporary jihadism does not solely deal with interpersonal links, Osama bin Laden gained a highly charismatic profile within the movement, making him a naturally powerful leader. His videos and statements still resonate in the ears, hearts and minds of extremists and sympathisers. Following the announcement of his death, the various online testimonies aired by sympathisers and jihadist websites revealed that bin Laden strongly mattered and that his death, in one way or another, is a watershed[80]. Even if al-Qaeda can no longer conduct a large-scale 


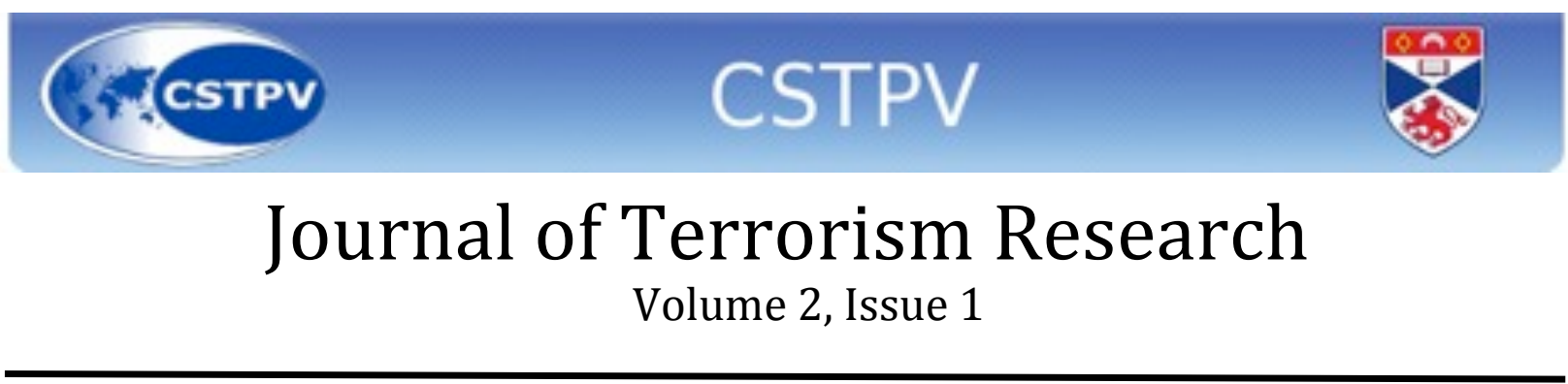

terrorist attack, "al-Qaeda leaders continue to highlight potential targets and transmit operational directives"[81]. Terrorist attacks in Saudi Arabia[82] and the Madrid bombings occurred months after Osama bin Laden had himself threatened those countries with the likelihood of a bombing.

\section{Kinship and friendship as a first step into global jihad}

Furthermore, increasing evidence shows that friendship, kinship and word of mouth contacts are becoming an increasingly essential feature of the contemporary jihadist movement's organisational structure. Further police investigations in the wake of terrorist attacks have unveiled the very nature of these "home-grown" networks, especially in Europe. In the case of the Madrid bombings and Theo van Gogh's killing, initial descriptions of "self-financed, selfsufficient and self-radicalised'[83] cells turned out to be partially wrong or at least too shortsighted. The Madrid bombers were not home-grown terrorists. Mostly from Moroccan, Algerian, and Syrian backgrounds[84], these extremists were in fact all linked though the Abu Dahdah[85] network. As an al-Qaeda operative in Spain[86], he had extensive contacts with European jihadist circles in London such as influential al-Qaeda ideologue Abu Musab al-Suri[87] and alAnsar editor Abu Qatada[88]. Further evidence shows that this network was also closely collaborating with the Moroccan Islamic Combatant Group[89], itself linked to jihadists in Europe, Saudi Arabia and Afghanistan[90]. This complex web of links shows the global aspect that shapes the jihadist movement. Terrorist cells in Europe in the post-9/11 environment are defined by Jordan, Manas and Horsburgh as "grassroot jihadist networks"[91]. In their view, these networks embody "individuals that operate within the country that they reside and share the strategic objectives of the Global Jihad Movement (GJM) but do not formally belong to the 'AlQaeda organisation' or other associated groups"[92]. Unquestionably they are part of "a wider hierarchical organization, and depend on the directives of that organization at strategic and operational levels"[93] and embrace this jihadist narrative. This definition of "grassroot jihadist networks" fits the descriptions of the Madrid bombers' network, the 7/7 London suicide bombers and the Hofstad Group well. These individuals, either European-born or European immigrants, were radicalised in Europe through friendship and kinship. Indeed, political violence and terrorism may not be embraced by a personal move towards radicalism. One's grievances, whether social, religious, political or economic, have to be framed into a narrative that resonates. All potential causes of terrorism, such as anger, political frustration, feelings of humiliation or despair may impact on one's behaviour, particularly if these beliefs are commonly shared and felt. Terrorism clearly is a group process. Framing terrorism into a "group adventure"[94] may contribute to an understanding of how individuals turned their backs on their own societies or 


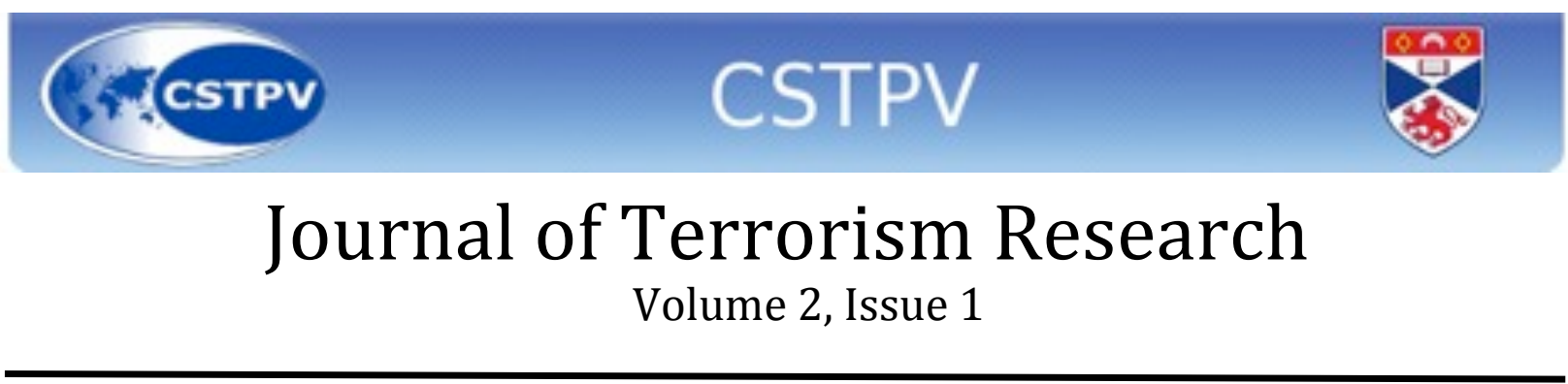

their countries of residence. For instance, an account of the formation of the Hofstad Group in the Netherlands indicates that most group members originated from the Rif Valley in Northern Morocco. An analysis of the Madrid network members similarly illustrates that the group grew by word of mouth. Some members, radical Muslims, encouraged their friends who felt some degree of alienation to join this terrorist cell[95]. In the meantime, European governments conducted hundreds of arrests of would-be jihadists across the continent[96], showing that the continent is not immune to the threat of "Europe's angry Muslims,"[97] in Robert Leiken's words. The same thing can be said about the deadliest terrorist cell that emerged from Europe, the Hamburg cell. In the late 1990s, Hamburg was the place where Mohammed Atta, Ziad Jarrah and Marwan al-Shehhi met, socialised and were radicalised during their university years. In the case of those three 9/11 pilots, they had become involved in radicalism in Europe, and sought alQaeda guidance. They, typically, offered al-Qaeda their skills, not the other way around. Therefore, it can be said that within the contemporary jihadist movement "the main groups did not recruit individuals. Rather, they entered the movement"[98].

This divided type of leadership, social bonds between individuals and Osama bin Laden's charismatic authority have characterised the evolution of the jihadist movement towards a highly decentralised structure after the $9 / 11$ attacks. Contemporary jihadism on the global scale as it has been previously defined differs from the hierarchical terrorist organisation that directly planned the 1998 East Africa embassy attacks, the USS Cole attack in Aden and 9/11. Over the last decade, the franchising of jihadism has been embodied by the growing use of affiliated terrorist groups or less importantly inspired sympathisers who crossed the violence threshold to carry out deadly acts on behalf of this extremist, violent and deviant ideology. In other words and despite the post-9/11 global crackdown on al-Qaeda leaders and operatives, al-Qaeda has managed to maintain its resilience in the international system by subcontracting its deadly acts of terror to individuals and groups ready to take up the challenge on its behalf. Bouyeri, Khan, the Madrid bombers, Indonesian and Pakistani terrorists among many others all put into practice bin Laden and Zawahiri's various calls for indiscriminate violence against their numerous identified enemies, ranging from Western military personnel to Muslim and non-Muslim innocent civilians.

To conclude, leadership in the contemporary jihadist movement has been dispersed well beyond its most visible spokespersons like late Osama bin Laden or Ayman al-Zawahiri. It has become more elusive to deal with. As a consequence, the complex structure of contemporary jihadism has reinforced its resilience and made the fight against jihadist violence more difficult for governments, security departments and intelligence agencies. The fact that leadership still 


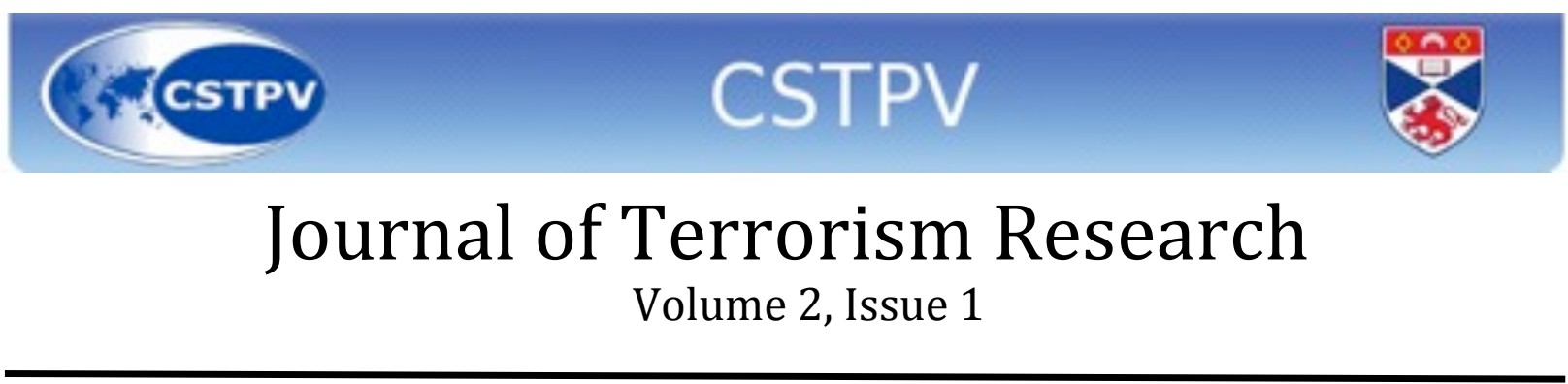

matters shows that at some point hierarchy and personal authority remain a critical feature of the jihadist movement too. Despite its highly decentralised nature, today's global jihadism still requires leadership so that the movement's followers can move forward with their plans and fulfil the agenda. Should Osama bin Laden and the extremist ideology he stood for stop being an inspirational force for radicals, campaigns of terrorist violence in the name of jihad could possibly wane in the medium term. Now that the ten-year-long manhunt for the capture of Osama bin Laden came to an abrupt end, the issue of leadership within the jihadist movement has become all the more essential. Still regarded as an operational success, the targeted killing of Osama bin Laden has now widened the window of opportunity for commentaries and predictions about the next command-and-control structure that al-Qaeda is likely to adopt. Despite it is too early to draw some definite conclusions, what now needs to be discussed in the coming weeks and months are the possible scenarios[99]. The death of Osama bin Laden is not synonymous to the end of contemporary jihadism, as hierarchy in al-Qaeda did not essentially matter as much as it would for other traditional terrorist organisations that suffered a clear decline after the killing or the arrest of their leader, such as Shoko Asahara in Aum Shinrikyo. Nevertheless, this targeted killing, after dozens of senior al-Qaeda operatives, military commanders and militants were arrested or killed over the last decade, symbolises the loss of impetus taken by contemporary jihadism. Whether al-Qaeda central has the ability to perform a transfer of leadership to a new leader in order to survive his founder's death is still unknown and hard to guess. The two most visible scenarios that might emerge for the future of the jihadist movement depend on the view one has about global jihad, as represented summarily by the 2008 debate between Marc Sageman and Bruce Hoffman. Thus, from an al-Qaeda central perspective, the next phase of jihadism depends on the possibility for al-Qaeda to name a new leader, such as bin Laden's long-time deputy and al-Qaeda ideologue Ayman al-Zawahiri, propaganda chief Abu Yahya al-Libi, or less prominent contenders, to continue to send orders and provide general guidance[100]. From a more networked approach, the resilience of jihadism will be assessed on whether the seeds of terror have sufficiently been diffused among the wide jihadist circle of sympathisers globally to sustain the struggle in this post-bin Laden era.

Romain Bartolo completed a Master of Counter-Terrorism Studies from Monash University in December 2010. He also holds a master's degree in International Security and Defence from University Jean Moulin Lyon 3. His main areas of research focus on Islamism and jihadism, deradicalisation and disengagement, and the prevention of political extremism in multi-religious societies. 


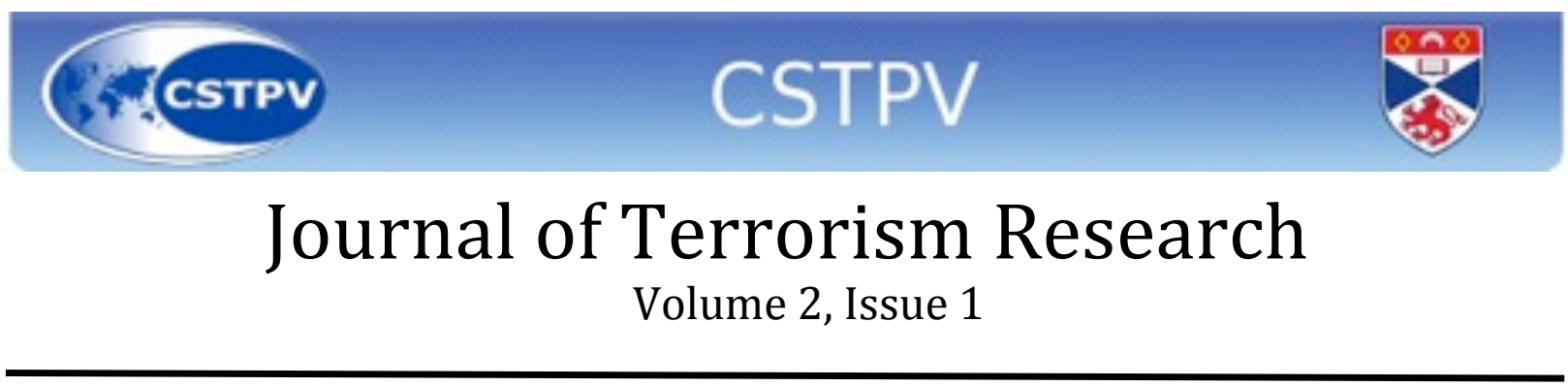

\section{Bibliography}

Bergen, P. (2008) 'Al Qaeda, the Organization: A Five-Year Forecast,' / The ANNALS of the American Academy of Political and Social Science / (618) pp. 14-30

Burke, J. (2004) 'Al Qaeda,' / Foreign Policy / (142) pp. 18-26

Cruickshank, P. \& Ali, M. H. (2007) 'Abu Musab Al Suri: Architect of the New Al-Qaeda', / Studies in Conflict and Terrorism / (30:1) pp.1-14

Farrall, L. (2011) 'Wanted. Charismatic Terror Mastermind. Some Travel Required.' /

ForeignPolicy.com /

Filiu, J-P. (2009) / Les Neuf Vies d'Al-Qaïda / (Paris) Fayard

Gerges, F. A. (2005) / Journey of the Jihadist: Inside Muslim Militancy / (Orlando) Harcourt Gunaratna, R. (2003) 'The New Face of Al Qaeda: Understanding the Generational Gradient in Local and Global Jihad Campaigns,' / Pointer Journal/ (29:4)

Hoffman, B. (2004) 'The Changing Face of Al Qaeda and the Global War on Terrorism,' / Studies in Conflict and Terrorism / (27:6) pp. 549-560

Hoffman, B. (2009) 'Radicalization and Subversion: Al Qaeda and the 7 July 2005 Bombings and the 2006 Airline Bombing Plot,' / Studies in Conflict and Terrorism / (32:12) pp.1100-1116 Jackson, B. A. (2006) 'Groups, Networks or Movements: A Command-and-Control-Driven Approach to Classifying Terrorist Organizations and Its Application to Al Qaeda,' / Studies in Conflict and Terrorism / (29:3) pp. 241-262

Jordan, J., \& Horsburgh, N. (2005) 'Mapping Jihadist Terrorism in Spain,' / Studies in Conflict and Terrorism / (28) pp. 165-191

Jordan, J., Manas, F. M. \& Horsburgh, N. (2008) 'Strengths and Weaknesses of Grassroot Jihadist Networks: The Madrid Bombings,' / Studies in Conflict and Terrorism / (31:1) pp.17-39 Juergensmeyer, M. (2000) / Terror in the Mind of God: The Global Rise of Religious Violence / (London \& Los Angeles) University of California Press

Kepel, G. (2004) 'Striking at the faraway enemy,' in / The War for Muslim Minds: Islam and the West / (Cambridge) Harvard University Press / pp.70-104

Leiken, R. S. (2005) 'Europe's Angry Muslims,' / Foreign Policy / (84:4)

Lentini, P. (2008a) 'Antipodal terrorists? Accounting for differences in Australian and 'Global'

Neojihadists,' in Devetak, R. \& Hughes, C. W. (eds), Globalization's Shadow: The Globalization of Violence / (London) Routledge / pp. 181-202

Lentini, P. (2008b) 'The Transference of Neojihadism: Towards a Process Theory of Transnational Radicalisation,' / in Khatab, S., Bakashmar, M. \& Ogru, E. (eds), Radicalisation Crossing Borders: New Directions in Islamist and Jihadist Political, Intellectual, and 


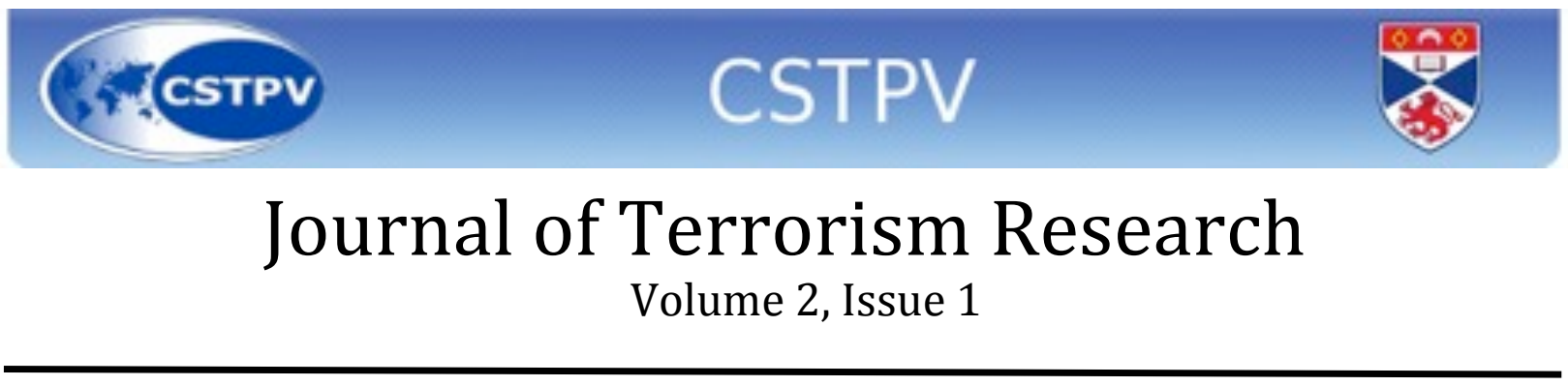

Theological Thought in Practice / Global Terrorism Research Centre, Monash University, 2009. Refereed Proceedings from the GTReC International Conference, 26-27 November 2008, Parliament House, Melbourne, Victoria / pp. 1-32

Lia, B. (2008) 'Doctrines for Jihadi Training,' / Terrorism and Political Violence / (20:4) pp. 518-542

Lynch, M. (2010) 'Islam Divided Between Salafi-jihad and the Ikhwan,' / Studies in Conflict and Terrorism / (33:6) pp.467-487

Maher, Shiraz, \& Meleagrou-Hitchens, Alexander (2011) 'ICSR Insight - Jihadist Forums React to Osama bin Laden's Death,' / FREErad!cals/ available at http://icsr.info/blog/ICSR-Insight--Jihadist-Forums-React-to-Osama-bin-Ladens-Death-

Marret, J-L (2007) 'Al-Qaeda in Islamic Maghreb: A 'Glocal' Organization,' / Studies in Conflict and Terrorism / (31:6) pp. 541-552

McAllister, B. (2004) 'Al-Qaeda and the Innovative Firm: Demythologizing the Network,'/

Studies in Conflict and Terrorism / (27:4) pp.297-319

Mishal, S. \& Rosenthal, M. (2005) 'Al Qaeda as a Dune Organization: Toward a Typology of Islamic Terrorist Organizations,' / Studies in Conflict and Terrorism / (28:4), pp. 275-293 Nasiri, O. (2006) / Inside the Global Jihad: How I infiltrated Al Qaeda and was Abandoned by Western Intelligence / (Carlton North) Scribe Publications

Nesser, P. (2006) 'Jihadism in Western Europe After the Invasion of Iraq: Tracing Motivational Influences from the Iraq War on Jihadist Terrorism in Western Europe,' / Studies in Conflict and Terrorism / (29:4) pp. 323-342

Nesser, P. (2008) 'How did Europe's Global Jihadis Obtain Training for their Militant Causes?' / Terrorism and Political Violence / (20:2) pp.234-256

Poncet, J-F \& Cerisier-benGuiga, M. (2009) 'Où en est al-Qaïda ?' / Rapport d'information $n$ ${ }^{\circ} 630$ au Sénat français sur la situation au Moyen-Orient / (Paris) / pp.105-113

Roggio, B. (2011) 'After bin Laden: who will lead al Qaeda?' / The Long War Journal /

Roy, O. (2004) / L'islam mondialisé / (Paris) Seuil, 2002, $2^{\text {nd }}$ ed.

Roy, O. (2009) 'Al-Qaeda in the West as a Youth Movement: the Power of a Narrative,' / in Emerson, M (ed), Ethno-Religious Conflict in Europe: Typologies of Radicalisation in Europe's Muslim Communities / (Brussels) Centre for European Policy Studies / pp. 11-26

Sageman, M. (2008) / Leaderless Jihad: Terror Networks in the Twenty-First Century / (Philadelphia) University of Pennsylvania Press

Sawyer, R. \& Foster, M. (2008) 'The Resurgent and Persistent Threat of al Qaeda' / The ANNALS of the American Academy of Political and Social Science / (618) pp. 197-211 


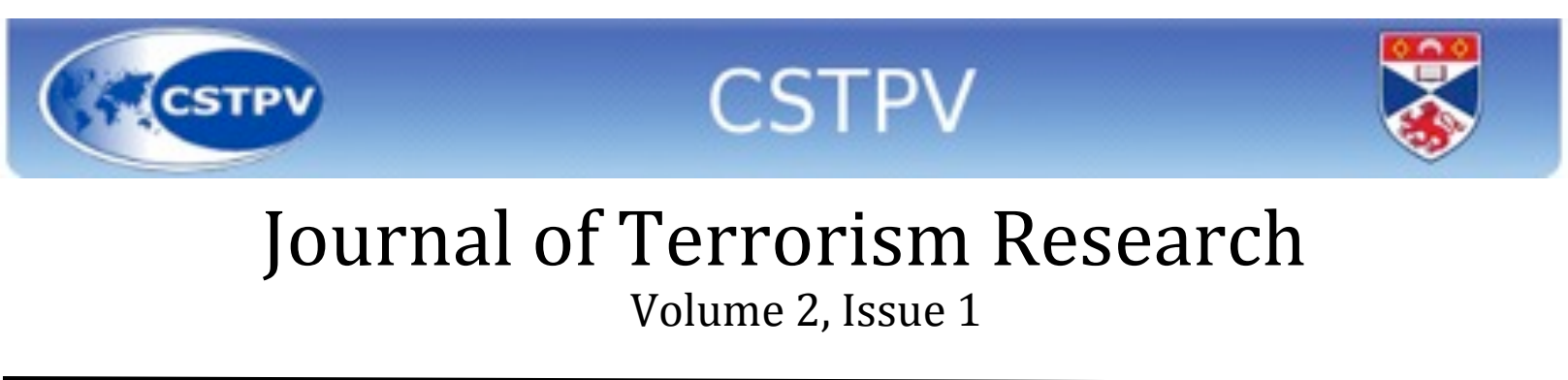

Silber, M. \& Bhatt, A. (2007) / Radicalisation in the West: The Homegrown Threat / (New York) New York City Police Department

Stenersen, A. (2008) 'The Internet: A Virtual Training Camp?', / Terrorism and Political Violence / (20:2) pp.215-233

Touraine, A. (2002) 'The Importance of Social Movements,' / Social Movement Studies / (1:1) pp.89-95

Wieviorka, M. (2005) 'After New Social Movements,' / Social Movement Studies / (4:1) pp.1-19 Wiktorowicz, Q. (2006) 'Anatomy of the Salafi Movement,' / Studies in Conflict and Terrorism / (29:3) pp.207-239

Zabel, S. E. (2007) / The military strategy of Global Jihad / (Carlisle) Strategic Studies Institute, US Army War College

\section{Notes}

[1] Bergen, P. (2008) 'Al Qaeda, the Organization : A Five-Year Forecast' / The ANNALS of the American Academy of Political and Social Science / (618) p. 17

[2] Nesser, P. (2006) 'Jihadism in Western Europe After the Invasion of Iraq : Tracing Motivational Influences from the Iraq War on Jihadist Terrorism in Western Europe,'/ Studies in Conflict and Terrorism / (29:4), p. 329

[3] Nonetheless, the Madrid bombings were not the first terrorist attacks carried out by radical Islamists in Europe. In 1995, France had been the target of a severe wave of public transport bombings carried out by the Algerian GIA (Groupe Islamique Armé) whose operations were led by Algerians as well as French-born citizens of Algerian descent, such as Khaled Kelkal for instance.

[4] Juergensmeyer, M. (2000) / Terror in the Mind of God: The Global Rise of Religious Violence / p. 5

[5] Of the forty-five members of the Madrid network, twenty-two were married and twenty-two were single. The forty-fifth's marital status remains unknown. In Jordan, J., Manas, F. M. \& Horsburgh, N. (2008) 'Strengths and Weaknesses of Grassroot Jihadist Networks: The Madrid Bombings,' / Studies in Conflict and Terrorism / (31:1) p. 22

[6] Sageman, M. (2008) / Leaderless Jihad: Terror Networks in the Twenty-First Century / (Philadelphia) University of Pennsylvania Press

[7] Statement credited to Jason Burke in Jackson, B. A. (2006) 'Groups, Networks, or Movements: A Command-and-Control-Driven Approach to Classifying Terrorist Organizations and Its Application to Al Qaeda,' / Studies in Conflict and Terrorism / (29) p. 256

[8] Statement credited to Pete Lentini. See Lentini, P. (2008b) 'The Transference of Neojihadism : Towards a Process Theory of Transnational Radicalisation' / in Khatab, S., Bakashmar, M. \& Ogru, E. (eds), Radicalisation Crossing Borders : New Directions in Islamist and Jihadist Political, Intellectual, and Theological Thought in Practice / Global Terrorism Research Centre, Monash University, 2009. Refereed Proceedings from the GTReC International Conference, 26-27 November 2008, Parliament House, Melbourne, Victoria / pp. 1-32.

[9] Jordan, J., Manas, F. M. \& Horsburgh, N. (2008) ‘Strengths and Weaknesses of Grassroot Jihadist Networks: The Madrid Bombings,'/ Studies in Conflict and Terrorism / (31:1) p. 17

[10] In 1928, Hasan al-Banna founded the Egyptian Muslim Brotherhood as the first Islamist political organisation in the Muslim world.

[11] Roy, O. (2004) / L'islam mondialisé / p. 33

[12] After gaining independence in 1945, Indonesia was mainly defined by a state ideology called Pancasila under Sukarno's rule. While acknowledging six official religions, Indonesia remained a secular regime. Shortly after the toppling of the Egyptian King, President Nasser as well as his successor President Anwar al-Sadat had cracked down on Islamist militants. The hanging of Sayyid Qutb in 1966 and President Sadat's assassination in 1981 illustrate this harsh showdown. As a general rule, Islamists became the only viable and serious alternative to secular governments because of rampant corruption affecting traditional opponents. For instance, the Muslim Brothers in Egypt and Syria were by far the only viable political force to oppose nationalist and secular governments. 


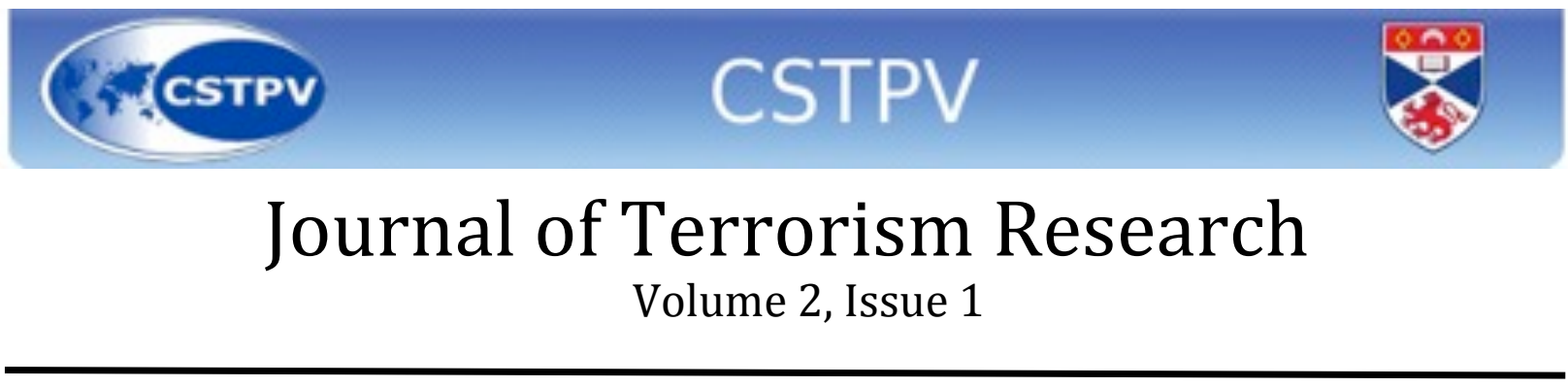

[13] Fawaz Gerges claims that "Muslims and 'Islamists' do not agree on what Islam is", in Gerges, F. A. (2007) / Journey of the Jihadist: Inside Muslim Militancy / p. 12

[14] Some Islamist movements are mainly devotional, such as the revivalist Tablighi Jamaat founded in 1925 by Mohamed Ilyas in India, which emphasises the role of $d a^{\prime} w a$ (proselytism). Others are explicitly political. Many Islamists entered politics in order to achieve their goals: in Iran, the Refah movement in Turkey, the Muslim Brotherhood, the Islamist Salvation Front in Algeria, Hizbullah in Lebanon, Hamas in Palestine...

For a more detailed list, see Roy, O. (2004), op. cit., p.34

[15] Lynch, M. (2010) 'Islam Divided Between Salafi-jihad and the Ikhwan,' / Studies in Conflict and Terrorism / (33:6)

[16] Ibid., p. 474

[17] Ibid.

[18] Ibid., p. 471

[19] Lentini, P. (2008a) 'Antipodal terrorists? Accounting for differences in Australian and 'Global' Neojihadists,' / in Devetak, R. \& Hugues, C. W. (eds), Globalization's Shadow : The Globalization of Violence / p.183

[20] Wiktorowicz, Q. (2006) 'Anatomy of the Salafi Movement,' / Studies in Conflict and Terrorism / (29:3) pp. 207-239

[21] Ibid., pp. 207-208

[22] Ibid., p. 207 \& p. 225

[23] Ibid., p. 207

[24] Ibid., p. 218

[25] Ibid., p. 208

[26] Zabel, S. E. (2007) / The military strategy of Global Jihad / p. 1

[27] Nesser, P. (2008) 'How did Europe’s Global Jihadis Obtain Training for their Militant Causes ?' / Terrorism and Political Violence / (20:2) p. 251

[28] The near enemy includes Muslim states that are not governed according to sharia law. Some countries fought in alliance with the 'far enemy', for example the relationship between the US and Saudi Arabia, or the 1978 peace treaty between Egypt and Israel. The near enemy mainly aims at toppling these Muslim regimes. The far enemy includes particularly the US and Israel, then European countries and other international actors that are defined as enemies of Islam.

[29] Al-Qaeda was founded in 1988 in Peshawar, Pakistan, by Abdullah Azzam. See Filiu, J-P (2009) / Les Neuf Vies d'Al-Qaïda / p. 46

[30] The most prominent al-Qaeda affiliated groups are al-Qaeda in the Arabian Peninsula, the Abu Sayyaf Group, the Egyptian Islamic Jihad, the Islamic Army of Aden, the Islamic Movement of Uzbekistan, Lashkar-e-Toiba, Kumpulan Mujahidin Malaysia, the Moro Islamic Liberation Front, Jemaah Islamiyah.

[31] Kepel, G. (2004) 'Striking at the faraway enemy,' / in The War for Muslim Minds, Islam and the West / p. 71

[32] Touraine, A. (2002) 'The Importance of Social Movements,' / Social Movement Studies / (1:1) p. 89

[33] Please refer to Nasiri, O. (2006), / Inside the Global Jihad: How I Infiltrated Al Qaeda and was Abandoned by Western Intelligence / And particularly to "The Land of Jihad is Wide", p. 234.

[34] Wieviorka, M. (2005) 'After New Social Movements,' / Social Movement Studies / (4:1) p. 14

[35] Hoffman, B. (2004) 'The Changing Face of Al Qaeda and the Global War on Terrorism,' / Studies in Conflict and Terrorism / (27:6) p. 556

[36] Burke, J. (2004) 'Al Qaeda,' / Foreign Policy / (142) p. 18. Similarly, Bruce Hoffman stated that "Al-Qaeda today [in 2004] has become more an idea or a concept than an organization”. See Hoffman, B., op. cit., p. 552.

[37] Gunaratna, R. (2003) 'The New Face of Al-Qaeda : Understanding the Generational Gradient in Local and Global Jihad Campaigns,' / Pointer Journal / (29:4) p. 12

[38] McAllister, B. (2004) 'Al-Qaeda and the Innovative Firm : Demythologizing the Network,' / Studies in Conflict and Terrorism / (27:4) p. 302

[39] Hoffman, B (2004), op. cit., p. 553 
[40] 'The international mobilisation against terrorism, from Autumn 2001, has deprived global jihad of its Afghan sanctuary',/ in Poncet, J-F \& Cerisier-benGuiga, M. (2009), 'Où en est Al-Qaïda?' / Rapport d'Information nº30 du Sénat français sur la situation au Moyen-Orient / p. 108. Personal translation of « La mobilisation internationale contre le terrorisme, à partir de l'automne 2001, prive le jihad global de son sanctuaire afghan ».

[41] Sawyer, R. \& Foster, M. (2008) 'The Resurgent and Persistent Threat of al Qaeda,' / The ANNALS of the American Academy of Political and Social Science / (618) p. 203

[42] Mohammed Atef was killed in Afghanistan in a US bombing in 2001.

[43] 9/11 mastermind Khalid Sheikh Mohammed was arrested in Pakistan in March 2003.

[44] Jemaah Islamiyah operational leader Hambali was captured in Southern Thailand in 2003. He was also the only non-Arab member of alQaeda's shura and the main middleman between al-Qaeda and South East Asian Jemaah Islamiyah.

[45] Sawyer, R. \& Foster, M. (2008), op. cit., p.197

[46] 'Al-Qaeda is only one part of a larger Salafist constellation', Ibid., p.204

[47] Kepel, G. (2004), op. cit., p.91

[48] Roy, O. (2009) 'Al-Qaeda in the West as a Youth Movement : The Power of a Narrative,' / in Emerson, M. (ed.), Ethno-Religious Conflict in Europe: Typologies of Radicalisation in Europe's Muslim Communities / p. 19

[49] Ibid.

[50] Between 2005 and 2008, forty terrorist organisations swore allegiance to Osama bin Laden and al-Qaeda. In Sawyer, R. \& Foster, M. (2008), op. cit., p.207

[51] In September 2006, the GSPC swore allegiance to Osama bin Laden. The GSPC became al-Qaeda in the Islamic Maghreb in January 2007 and remains the largest jihadist network in Western Europe. See Bergen, P. (2008), op. cit., p.17

[52] Marret, J-L (2007) ‘Al-Qaeda in Islamic Maghreb : A 'Glocal' Organization,'/ Studies in Conflict and Terrorism / (31:6) p. 549

[53] Gunaratna, Rohan (2003), op. cit., p. 12

[54] McAllister, B. (2004), op. cit., p. 308

[55] Marret, J-L (2007), op. cit., p. 549

[56] In Shaul Mishal and Maoz Rosenthal's view, "al-Qaeda remains one of the most significant threats to the Western world in general and to US national security in particular”. In Mishal, S. \& Rosenthal, M. (2005) 'Al Qaeda as a Dune Organization: Toward a Typology of Islamic Terrorist Organizations,' / Studies in Conflict and Terrorism / (28:4) p. 276

[57] Marret, J-L (2007), op. cit., p. 543

[58] Sageman, M. (2008), op. cit., p. 136

[59] Roy, O. (2009), op. cit., p. 12

[60] Ibid.

[61] Jackson, B. A. (2006) 'Groups, Networks, or Movements : A Command-and-Control-Driven Approach to Classifying Terrorist Organizations and Its Application to Al Qaeda,'/ Studies in Conflict and Terrorism / (29:3) p. 248

[62] Ibid., p. 250

[63] Bergen, P. (2008), op. cit, p. 15

[64] Sageman, M. (2008), op. cit., p. 133

[65] Gunaratna, R. (2003), op. cit., p. 3

[66] CNN journalist Peter Bergen interviewed Osama bin Laden in 1997.

[67] Stenersen, A. (2008) ‘The Internet : A Virtual Training Camp ?’ / Terrorism and Political Violence / (20:2) pp. 215-233

[68] The Arabic translation is 'nizam, la tanzim'. In Lia, B. (2008) 'Doctrines for Jihadi Training,' / Terrorism and Political Violence / (20:4) p. 533 
[69] Silber, M. \& Bhatt, A. (2007) / Radicalisation in the West: The Homegrown Threat

[70] According to the authors, the "spiritual sanctioner" is the main character behind the radicalisation and indoctrination phases. Consequently, he disposes of a certain leverage to convince fellow individuals who are radical but still undecided about whether or not to embrace the call for violence. Ibid., p. 38

[71] Ibid., p. 27

[72] Ibid., p. 51

[73] Ibid., p. 43

[74] Ibid., p. 87

[75] Nesser, P. (2006) 'Jihadism in Western Europe After the Invasion of Iraq : Tracing Motivational Influences from the Iraq War on Jihadist Terrorism in Western Europe,' op. cit., p. 334

[76] Ibid.

[77] Hoffman, B. (2009) 'Radicalization and Subversion : Al Qaeda and the 7 July 2005 Bombings and the 2006 Airline Bombing Plot,' / Studies in Conflict and Terrorism / (32:12) p. 1102

[78] Only Germaine Lindsay was born overseas in Jamaica. Mohammed Siddique Khan, Shehzad Tanweer and Hasib Hussain were all Britishborn and second-generation immigrants from Pakistan.

[79] Nesser, P. (2006), op. cit., p. 337-338

[80] Some testimonies have been put online by FREErad!cals, the International Centre for the Study of Radicalisation blog. See Maher, Shiraz, \& Meleagrou-Hitchens, Alexander, 'ICSR Insight - Jihadist Forums React to Osama bin Laden's Death', FREErad!cals, available at http://icsr.info/ blog/ICSR-Insight---Jihadist-Forums-React-to-Osama-bin-Ladens-Death-

[81] Jordan, J., Manas, F. M. \& Horsburgh, N. (2008), op. cit., p. 24

[82] Similarly, a video of Osama bin Laden was released in December 2004. His speech focused on attacking Saudi oil facilities. Over a year later in February 2006, the Abqaiq facility was targeted by a bombing. In Bergen, P. (2008), op. cit., p. 17

[83] Sageman, M. (2008), op. cit., p. viii (preface)

[84] Thirty-two of the forty-five Madrid network members were Moroccan, six were Syrian and five were Algerian. See Jordan, J., Manas, F. M. \& Horsburgh, N. (2008), op. cit., p.21

[85] Abu Dahdah was arrested in Spain in November 2001.

[86] Jordan, J. \& Horsburgh, N. (2005) 'Mapping Jihadist Terrorism in Spain,' / Studies in Conflict and Terrorism / (28:3) p. 172

[87] In the 1990s, Abu Musab al-Suri settled in London as did many other Islamists in what was then called "Londonistan" by French intelligence services. Furthermore, al-Suri links to the GIA show how complex the web of jihadism was in Western Europe. In Cruickshank, P. \& Ali, M. H. (2007) 'Abu Musab Al Suri: Architect of the New Al-Qaeda,' / Studies in Conflict and Terrorism / (30:1) p. 4

[88] Jordan, J. \& Horsburgh, N. (2005), op. cit., p. 176

[89] Nesser, P. (2006), op. cit., p. 327

[90] Ibid., p. 328

[91] Jordan, J., Manas, F. M. \& Horsburgh, N. (2008), op. cit., p. 17

[92] Ibid.

[93] Ibid., p. 19

[94] Sageman, M. (2008), op. cit., p. 70

[95] Jordan, J., Manas, F. M. \& Horsburgh, N. (2008), op. cit., p. 19

[96] Jihadists and would-be terrorists were arrested in many European countries following 9/11, such as in France, the UK, Spain, Italy, Sweden, Germany, the Netherlands... See Sageman, M. (2008), op. cit., p. 133

[97] Leiken, R. S. (2005) ‘Europe’s Angry Muslims,' / Foreign Policy / (84:4) 


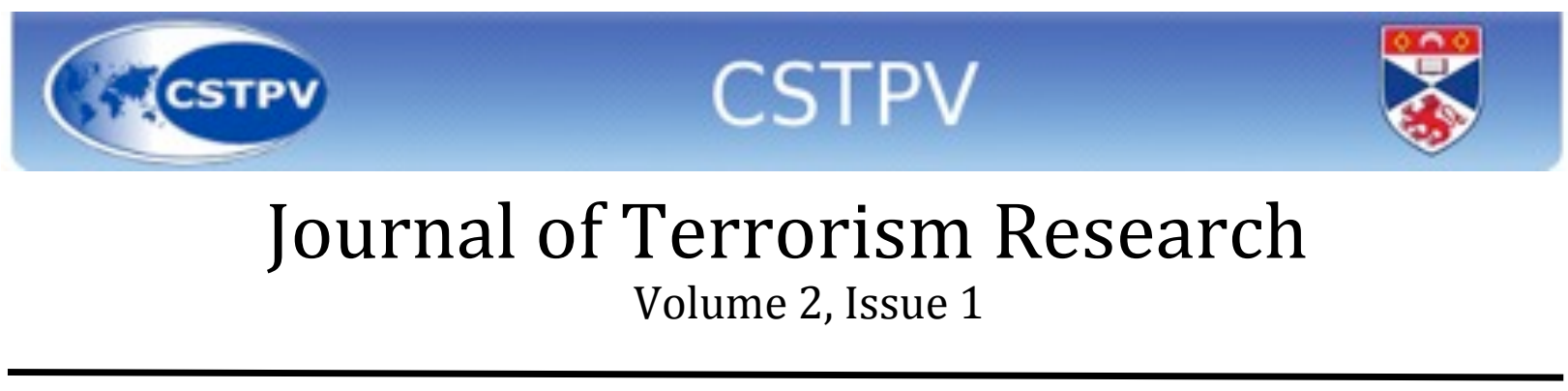

[98] Lentini, P. (2008a) ‘Antipodal terrorists? Accounting for differences in Australian and 'Global' Neojihadists,' op. cit., p. 190

[99] Farrall, L. (2011), 'Wanted. Charismatic Terror Mastermind. Some Travel Required.' / ForeignPolicy.com

[100] Roggio, B. (2011), 'After bin Laden: who will lead al Qaeda?' / The Long War Journal / 